University of Massachusetts Amherst

ScholarWorks@UMass Amherst

Chemistry Department Faculty Publication Series

Chemistry

2010

\title{
Phytoprotective influence of bacteria on growth and cadmium accumulation in the aquatic plant Lemna minor
}

\author{
Lisa M Stout \\ University of Massachusetts Amherst \\ Elena N Dodova \\ University of Massachusetts Amherst \\ Julian Tyson \\ University of Massachusetts Amherst \\ Klaus Nusslein \\ University of Massachusetts Amherst
}

Follow this and additional works at: https://scholarworks.umass.edu/chem_faculty_pubs

Part of the Chemistry Commons

\section{Recommended Citation}

Stout, Lisa M; Dodova, Elena N; Tyson, Julian; and Nusslein, Klaus, "Phytoprotective influence of bacteria on growth and cadmium accumulation in the aquatic plant Lemna minor" (2010). Water Research. 1351.

Retrieved from https://scholarworks.umass.edu/chem_faculty_pubs/1351 


\title{
Phytoprotective influence of bacteria on growth and cadmium accumulation in the aquatic plant Lemna minor
}

\author{
Lisa M. Stout ${ }^{a, 1}$, Elena N. Dodova ${ }^{b}$, Julian F. Tyson ${ }^{b}$, Klaus Nüsslein ${ }^{a, *}$ \\ ${ }^{a}$ Department of Microbiology, University of Massachusetts, Amherst, MA 01003-9298, USA \\ ${ }^{\mathrm{b}}$ Department of Chemistry University of Massachusetts, Amherst, MA 01003-9298, USA
}

Keywords:

Cadmium

Rhizosphere bacteria

Duckweed

Metal accumulation

\begin{abstract}
A B S T R A C T
Certain plants are known to accumulate heavy metals, and can be used in remediation of polluted soil or water. Plant-associated bacteria, especially those that are metal tolerant, may enhance the total amount of metal accumulated by the plant, but this process is still unclear. In this study, we investigated metal enhancement vs. exclusion by plants, and the phytoprotective role plant-associated bacteria might provide to plants exposed to heavy metal. We isolated cadmium-tolerant bacteria from the roots of the aquatic plant Lemna minor grown in heavy metal-polluted waters, and tested these isolates for tolerance to cadmium. The efficiency of plants to accumulate heavy metal from their surrounding environment was then tested by comparing L. minor plants grown with added metal tolerant bacteria to plants grown axenically to determine, whether bacteria associated with these plants increase metal accumulation in the plant.

Unexpectedly, cadmium tolerance was not seen in all bacterial isolates that had been exposed to cadmium. Axenic plants accumulated slightly more cadmium than plants inoculated with bacterial isolates. Certain isolates promoted root growth, but overall, addition of bacterial strains did not enhance plant cadmium uptake, and in some cases, inhibited cadmium accumulation by plants. This suggests that bacteria serve a phytoprotective role in their relationship with Lemna minor, preventing toxic cadmium from entering plants.
\end{abstract}

\section{Introduction}

Industrial effluent and urban runoff often contain toxic heavy metals such as cadmium, copper, zinc, nickel, and lead that pollute surface waters. The heavy metal cadmium (Cd) is found naturally in ores of zinc, lead, and copper. In unpolluted environments, Cd is usually found in very low concentrations, from $10 \mathrm{ng} / \mathrm{l}$ in fresh water to $1 \mathrm{mg} / \mathrm{kg}$ in soil, but anthropogenic sources can elevate Cd concentrations greatly (GLEC, 2000).
Cd has been shown to have a function in certain biological systems, namely algae (Lane et al., 2005), but even small amounts can be toxic to most organisms. In plants, toxic levels of Cd may cause stunting and chlorosis. Cd enters cells through uptake systems for other divalent cations, and interferes with other ions such as calcium, magnesium, phosphorus, and potassium inside the cell (Das et al., 1997). In humans, Cd can cause kidney and bone damage, and can also cause damage to lungs through inhalation (Dept. of Health and Human Services, 2008). Metallothioneins, cysteine-rich

\footnotetext{
* Corresponding author. Department of Microbiology, University of Massachusetts, 203 Morrill Science Center IV N, 639 North Pleasant St., Amherst, MA 01003-9298, USA. Tel.: +1 413545 1356; fax: +1 4135451578.

E-mail address: nusslein@microbio.umass.edu (K. Nüsslein).

${ }^{1}$ Present address: Department of Geology and Geophysics, Yale University, New Haven, CT 06511.
} 
metal-binding proteins, protect against toxicity to some degree (Klaassen et al., 1999). Additionally, Cd has been shown to cause single strand DNA damage in bacteria (Trevors et al., 1986). Cd is well studied in aquatic environments because it is particularly toxic to aquatic life. The United States Environmental Protection Agency has classified Cd as a priority pollutant and has set the maximum contaminant limit for $\mathrm{Cd}$ in drinking water at $5 \mu \mathrm{g} / \mathrm{l}$ (USEPA, 2004).

Phytoremediation is a term used to refer to the use of plants and their associated microbial communities to inactivate or remove pollutants from the environment. This is an emerging technology that can be used to remove heavy metals such as Cd (Flathman and Lanza, 1998; Salt et al., 1995). While some plants deal with toxic metals by exclusion mechanisms, other plants have the ability to accumulate heavy metals at extremely high concentrations, and sequester them in their tissues (Whiting et al., 2004). Plants that can accumulate metals at much greater concentrations than those found in the environment are termed hyperaccumulators, and there are numerous hyperaccumulators known for zinc/cadmium (Baker and Brooks, 1989). For cadmium, hyperaccumulators are defined as plants that accumulate $>100 \mathrm{mg} / \mathrm{kg}$ cadmium in dry weight of plants (Baker and Brooks, 1989). Hyperaccumulators may also be defined based on bioconcentration factor, or the ability to accumulate metals in plant tissues at high concentrations relative to the external soil or water environment (Zayed et al., 1998). For cadmium, a hyperaccumulator is defined as a plant that can accumulate greater than 1000 times the concentration of Cd (based on concentration of metal in dry weight of plant) than that in the surrounding medium (Zayed et al., 1998).

Aquatic and wetland plants including the water hyacinth Eichhornia crassipes (Agunbiade et al., 2009; Ingole and Bhole, 2003; Mishra and Tripathi, 2009; Zhu et al., 1999), the invasive reed Phragmites australis (Ghassemzadeh et al., 2008), and yellow velvetleaf Limnocharis flava (Abhilash et al., 2009) have been studied for their abilities to remove metals from aquatic systems. Strong attention has been focused on members of the Lemnaceae (duckweed) family, including Spirodela polyrhiza (Rahman et al., 2007), L. minor (Hou et al., 2007; Oporto et al., 2006; Uysal and Taner, 2009), and Lemna gibba (DelCampo Marin and Oron, 2007; Khellaf and Zerdaoui, 2009; Megateli et al., 2009; Mkandawire et al., 2004b), for their abilities to remove metals and metalloids from the environment. L. minor is a small aquatic angiosperm that grows in still waters, having a simple structure with a single root that is not anchored in sediment, and leaves that float on the water surface. This plant can live in many different environments and has a wide range of conditions for growth (Landolt and Kandeler, 1987). Under optimal conditions it can double every 2-3 days.

A number of studies in the past two decades have shown that L. minor can accumulate Cd in high concentrations in its fronds, and studies have focused on the use of L. minor to remove Cd from surface waters (Debusk et al., 1996; Hasar and Obek, 2001; Wang et al., 2002; Zayed et al., 1998). This plant is considered a good choice for remediation projects, because due to its rapid growth rate and ease of removal, it can be harvested at regular intervals (weekly or biweekly), keeping the metal from continuous reintroduction into the ecosystem (Debusk et al., 1996).

While studies have shown that L. minor can accumulate high levels of $\mathrm{Cd}$, it has also been shown that the plant cannot tolerate high concentrations of $\mathrm{Cd}$ in the surrounding water (Wang, 1990). Due to this sensitivity to dissolved metals L. minor has been also used to assess toxicity in the environment (USEPA, 1996). Signs of toxicity in L. minor may include chlorosis, stunting of growth, colony separation, and root detachment, and monitoring agencies continue to develop methods to use the plant as a toxicity indicator (APHA et al., 1992, GLEC, 2000).

Several phytoremediation studies have shown that rhizosphere bacteria contribute to plant metal tolerance and increased metal uptake (Crowley et al., 1992; De Souza et al., 1999; Salt et al., 1999; van der Lelie et al., 2000). Bacterial metal resistance has been described as a necessity for plantassociated bacteria in contaminated environments (Salt et al., 1999), and may be related to plant metal uptake, since the bioavailability of metals could be altered by expression of bacterial metal resistance systems (van der Lelie et al., 2000). While plants may protect bacteria from toxic metals in the surrounding medium by providing a surface for attachment as well as nutrients (Andrews and Harris, 2000), bacteria may also protect plants from metal toxicity, by mechanisms such as depositing metals outside of bacterial cell walls (Lodewyckx et al., 2002).

Often bacteria contain resistance systems, active mechanisms for removing or sequestering metals (Gadd, 1992). For cadmium, there are several types of resistance systems involving efflux pumps to remove metals from the cell (Nies, 2003). Bacteria may also express some level of metal tolerance due to production of EPS (Pagnanelli et al., 2003; Solisio et al., 1998), or accumulation of metals on their cell surfaces. This may allow for bacterial contribution to metal accumulation in the plant-microbe system. For example, heavy metalresistant strains of Azotobacter produced EPS, restricting the amount of $\mathrm{Cd}$ and $\mathrm{Cr}$ accumulated by wheat (Joshi and Juwarkar, 2009). Certain bacteria, known as plant growth promoting rhizobacteria, produce compounds that stimulate plant growth, even in the presence of metals, which allows greater metal accumulation by plants. Some of the most well characterized compounds include siderophores (Crowley et al., 1992) and indole-3-acetic acid (Leveau and Lindow, 2005).

In this study, we investigated the cadmium tolerance of isolates from the rhizoplane of L. minor, the implications these plant-associated bacteria have for enhanced metal removal, and the effects of enriching for these bacteria on plant growth and plant metal accumulation. While it has already been shown that L. minor is capable of accumulating high concentrations of cadmium, we hypothesized that under conditions where microbial growth is enhanced, cadmium accumulation in plants would also be enhanced due to stimulation of plant growth by microorganisms. We demonstrate that plant-associated bacteria exert a phytoprotective role for the plant, increasing the metal tolerance of sensitive Lemna plants while not increasing cadmium accumulation, most likely due to sequestration of metal at the microbial surface. 


\section{Materials and methods}

\subsection{Isolation of bacteria from plants with or without cadmium}

L. minor was obtained from two sources; laboratory-reared plants obtained from the US Environmental Protection Agency (EPA) and plants collected from Rice City Pond (RCP), a highly contaminated impoundment of the Blackstone River in Massachusetts (USA) (Table 1). Plants were previously identified by chloroplast ribosomal sequence analysis as L. minor, and plants were grown in the laboratory at $20^{\circ} \mathrm{C}$ under a photoperiod of $16 \mathrm{~h}$ light/8 h dark as described previously (Stout and Nüsslein, 2005).

EPA plants and RCP plants were used for 14-day treatments and were grown either with or without $100 \mu \mathrm{g} / 1 \mathrm{CdSO}_{4}$. This concentration was chosen as a test concentration based on literature reports and our previous test series that showed this as the lowest sublethal concentration of $\mathrm{Cd}$ to plants over two weeks (Huebert and Shay, 1991). EPA plants were shown to be more sensitive to $\mathrm{Cd}$, based on frond counts, than RCP plants (Table 2), and so EPA plants were used for axenic experiments due to their greater sensitivity, although both plants were used to obtain bacterial isolates. After 14 days, EPA and RCP

Table 1 - Reported water quality data for Rice City Pond surface water.

\begin{tabular}{lc} 
& $\mathrm{mg} / \mathrm{l}$ \\
\hline Conductivity* & $518^{\mathrm{a}}$ \\
$\mathrm{pH}^{*}$ & $6.8^{\mathrm{a}}$ \\
$\mathrm{DO}$ & $6.8^{\mathrm{a}}$ \\
$\mathrm{Ammonia}$, as N & $0.19^{\mathrm{b}}$ \\
$\mathrm{Ammonia}^{*}$ org N, as N & $0.86^{\mathrm{a}}$ \\
$\mathrm{NO}_{3}+\mathrm{NO}_{2}$, as N & $2.79^{\mathrm{a}}$ \\
$\mathrm{P}$ & $0.71^{\mathrm{a}}$ \\
$\mathrm{Cl}$ & $104^{\mathrm{b}}$ \\
$\mathrm{Pheophyton}$ & $7.4^{\mathrm{a}}$ \\
$\mathrm{chlA}$ & $6.99^{\mathrm{b}}$ \\
$\mathrm{BOD}$ & $3.7^{\mathrm{b}}$ \\
$\mathrm{TSS}$ & $7.35^{\mathrm{b}}$ \\
$\mathrm{VSS}$ & $3.17^{\mathrm{b}}$ \\
$\mathrm{Cd}$ & $1.75^{\mathrm{b}}$ \\
$\mathrm{Cr}$ & $0.010^{\mathrm{c}}$ \\
$\mathrm{Cu}$ & $0.019^{\mathrm{c}}$ \\
$\mathrm{Fe}$ & $1.770^{\mathrm{c}}$ \\
$\mathrm{Ni}$ & $0.018^{\mathrm{c}}$ \\
$\mathrm{Pb}$ & $0.016^{\mathrm{c}}$ \\
$\mathrm{Zn}$ & $0.019^{\mathrm{c}}$ \\
\hline
\end{tabular}

Data are in $\mathrm{mg} / \mathrm{l}$, unless otherwise noted; Conductivity is given in $\mu \mathrm{S} / \mathrm{cm}$; pH is shown in standard units; Pheophyton and chlA are given in $\mu \mathrm{g} / \mathrm{l}$.

$\mathrm{DO}=$ Dissolved oxygen; ChlA $=$ chlorophyll A; BOD = Biological Oxygen Demand; TSS $=$ Total Suspended Solids; VSS $=$ Volatile Suspended Solids.

a USGS: United States Geological Survey (USGS, 2004).

b USACE: United States Army Corps of Engineers. Wright, R. BacPhase 2. USACE, unpublished report. For phase I information, see (Wright et al., 2004). Values are averages for two month period of measurements in June-August 2001.

c USEPA: United States Environmental Protection Agency (Snook, 1996). Numbers are averages of values measured at intervals over a $24 \mathrm{~h}$ period.
Table 2 - Frond counts of EPA and RCP plants, grown in Cd or no Cd, as well as in either EPA or RCP water.

$\begin{array}{lr}\text { Plant Number } & \begin{array}{c}\text { \% growth of Cd } \\ \text { treated to no Cd }\end{array}\end{array}$

$\begin{array}{lrrr}\text { EPA plants } & & & \\ \text { In EPA water } & 30 & 243 & 66 \% \\ \text { In EPA water + Cd } & 30 & 172 & \\ \text { In RCP water } & 30 & 228 & 34 \% \\ \text { In RCP water + Cd } & 30 & 98 & \\ \text { RCP plants } & & & \\ \text { In RCP water } & 30 & 117 & 69 \% \\ \text { In RCP water + Cd } & 30 & 90 & 52 \% \\ \text { In EPA water } & 30 & 103 & \\ \text { In EPA water + Cd } & 30 & 68 & \end{array}$

Frond counts taken at start (t0) and end (t14) of 14-day treatments in different waters. In all cases, RCP plants grew slightly better in Cd than EPA plants. All plants showed a decrease in growth in solutions with $\mathrm{Cd}$ added compared to solutions without $\mathrm{Cd}$, and percentages given are the percentage of growth in $\mathrm{Cd}$ to that in the same water with no added Cd.

plants were placed on media plates using double concentrated ASTM nutrient solution (APHA et al., 1992) solidified with noble agar (ASTM medium). Plants from all treatments were plated on ASTM medium, ASTM medium with added plant extract (water from an overgrown culture of L. minor, filtered and added to medium at $1 / 4$ strength), and ASTM medium with added $0.1 \%$ glucose as a carbon source, all either with or without $100 \mu \mathrm{M} \mathrm{CdSO}_{4}\left(20 \mathrm{mg} / \mathrm{lCdSO}_{4}\right)$. Prior to placement on solid media, plants were rinsed with sterile distilled water to remove non-rhizoplane bacteria.

Isolates from plates were identified by $16 \mathrm{~S}$ rRNA analysis. PCR of isolates was performed directly from colonies using primers 8F and 1492R (Weisburg et al., 1991). PCR amplifications were prepared with $0.25 \mathrm{mM}$ each dNTP, $1 \mathrm{U} / 10 \mu \mathrm{l} \mathrm{Taq}$ polymerase, in $1 \times$ Buffer (all from Promega, Madison, WI), $1.5 \mathrm{mM} \mathrm{MgCl}_{2}$ (Sigma, St. Louis, $\mathrm{MO}$ ), $0.5 \mu \mathrm{M}$ of each primer (Integrated DNA Technologies, Coralville, IA), and DNA template in a final volume of $30 \mu \mathrm{l}$. Reactions were performed in a PTC-200 Peltier thermal cycler (MJ Research, Waltham, MA) and consisted of 30 cycles of $95^{\circ} \mathrm{C}$ for $30 \mathrm{~s}, 56^{\circ} \mathrm{C}$ for $30 \mathrm{~s}$, and $72{ }^{\circ} \mathrm{C}$ for $30 \mathrm{~s}$ with an initial denaturation at $95^{\circ} \mathrm{C}$ for $5 \mathrm{~min}$ and a final extension at $72{ }^{\circ} \mathrm{C}$ for $5 \mathrm{~min}$. PCR products were purified with the QIAquick PCR purification kit (Qiagen, Valencia, CA), quantified by comparison to PCR ladder V (PGC Scientifics, Frederick, MD) using a digital imaging system with LabWorks software (UVP, Upland, CA), and were directly sequenced. Sequencing reactions were prepared using the $A B I$ Big Dye 3.1 kit (Applied Biosystems, Foster City, CA). Dye terminator cycle sequencing reactions were prepared according to manufacturer's instructions with the primer $8 \mathrm{~F}$, and were sequenced with a model $3730 \times 1$ DNA Analyzer (Applied Biosystems, Foster City, CA). Sequences were edited using the software Chromas (www.technelysium.com.au/ chromas.html), and were compared to those in the RDP II database (Cole et al., 2003). Sequences were aligned using the Clustal interface in the software package BioEdit (Hall, 1999). Phylogenetic trees (Supplemental Fig. S4) were created with MEGA v.3 (Kumar et al., 2004), using the neighbor-joining 
algorithm with 1000 bootstrap replicates. Possible chimeras were detected using the Bellerophon server (Huber et al., 2004) and were examined more closely. One isolate, EPACd12, was flagged as a putative chimera, although rechecking with the Pintail software (http://www.bioinformatics-toolkit.org/WebPintail/) revealed no sequence anomalies.

\subsection{Characterization of metal tolerance in isolates}

To determine the range of cadmium tolerance in bacterial isolates from plants, isolates were transferred to Mineral Salts Medium (MSM), a medium recommended by Roane (Roane and Pepper, 1999) for testing bacterial growth in metals, for subsequent cadmium tolerance tests. Isolates were first tested for their ability to grow in MSM, and almost all isolates grew in MSM as well as in ASTM. ASTM medium was not used for these tests due to precipitation of cadmium at higher concentrations. Isolates were grown in six twofold dilutions with the highest at $10 \mathrm{mM}$ cadmium (as $\mathrm{CdSO}_{4}$ ) (and concentrations of $5,2.5,1.25,0.63,0.31,0.16 \mathrm{mM}$ ) and a control without cadmium, arranged in 96-well plates. Measurements were taken every 6-8 h with a SpectraMax 190 microplate reader (Molecular Devices, Sunnyvale, CA), over a period of $96 \mathrm{~h}$.

\subsection{Siderophore production}

Bacterial isolates were tested for siderophore production in order to determine whether they promoted plant growth by this means, thus allowing greater metal accumulation. Siderophore production in isolates was tested by plating colonies on chrome azurol S (CAS) medium (Schwyn and Neilands, 1987), using MSM with low citrate (0.1 g/l) as a base. Colonies producing siderophores changed the medium color around them from blue to orange.

\subsection{Axenic plant cultures}

EPA laboratory plants were surface-sterilized by submersion into a $0.1 \%$ bleach solution (from $5 \%$ sodium hypochlorite) for 5 min. Following treatment, plants were rinsed twice in distilled water and were plated onto agar containing $2 \times$ ASTM medium for recovery. Plants were allowed to grow at $20^{\circ} \mathrm{C}$ exposed to alternating photoperiods of $16 \mathrm{~h}$ light and $8 \mathrm{~h}$ dark, and were transferred onto new plates upon plant regeneration. Plants with no visible bacterial growth were further examined for surface sterility by placing them on the complex R2A medium and also by staining plant sections with the nucleic acid stain Syto-9 (Invitrogen, Carlsbad, CA), and visualizing by epifluorescence microscopy.

\subsection{Plant metal uptake with added bacteria}

Plant growth and plant metal accumulation were measured after the addition of isolates (Table 3 ) to the growth medium with metal-sensitive EPA axenic plants. Treatments with mixtures of all EPA or RCP isolates and mixtures of all isolates from EPA or RCP were also included. All experiments were conducted in triplicate (Supplemental Table S2). Experiments were set up in large glass culture tubes with $30 \mathrm{ml}$ medium containing ASTM solution (without EDTA) and $100 \mu \mathrm{g} / \mathrm{l} \mathrm{CdSO}_{4}$. This particular concentration was chosen as it was the highest concentration that was sublethal to the plants over the time period studied, but lower concentrations could be included in future studies. In order to stimulate bacterial growth, the final medium was amended with $0.1 \%$ glucose (Crowley et al., 1992). To each tube, $20 \mu \mathrm{l}$ of liquid culture in late exponential growth phase of the respective bacterial isolate was added to two plants in the two-frond stage of growth.

Growth rates based on frond counts and cadmium concentrations were measured. Every three days fronds were counted and other phenotypic observations were recorded. Growth rates were calculated as

$\mu=\ln N t_{2}-\ln N t_{1} / t_{2}-t_{1}$

where $N t$ is the number of fronds at time $t$ (Mkandawire et al., 2004a).

Two additional factors, including the $\mathrm{pH}$ value of the plant growth medium and root elongation, were also determined in these plant-bacterial growth experiments after 14 days, and compared to axenic plant controls. Student t-tests were conducted to compare growth of samples to the bacteria-free control.

Table 3 - Isolates used as amendments to axenic EPA plants.

\begin{tabular}{|c|c|c|c|}
\hline Seq ID & Sequence match from RDP & $\%$ Similarity & Isolation source \Plant/medium \\
\hline EPA 5 & Methylobacterium sp. iRIII1 & 100 & EPA/ASTM + Gluc + Cd \\
\hline EPA 6 & Microbacterium sp. S15-M3 & 95.7 & EPA/ASTM \\
\hline EPACd 7 & Flectobacillus sp. MWH38 & 94.7 & $\mathrm{EPA}+\mathrm{Cd} / \mathrm{ASTM}+$ Gluc $+\mathrm{Cd}$ \\
\hline EPACd 10 & Sporocytophaga cauliformis $9726 \mathrm{R}$ & 97.0 & $\mathrm{EPA}+\mathrm{Cd} / \mathrm{ASTM}+\mathrm{PE}+\mathrm{Cd}$ \\
\hline EPACd 12 & Limnobacter sp. HTCC376 & 99.3 & $\mathrm{EPA}+\mathrm{Cd} / \mathrm{ASTM}+\mathrm{PE}+\mathrm{Cd}$ \\
\hline RCP 5 & Methylophilus leisingeri DSM 6813 & 98.6 & RCP/ASTM + Gluc + Cd \\
\hline RCP 6 & Oxalobacteraceae bacterium MWH73 & 88.4 & RCP/ASTM + Gluc \\
\hline RCP 9 & Variovorax paradoxus Cwt6 & 100 & RCP/ASTM + Cd \\
\hline RCP C1 & Zoogloea ramigera ATCC 25935 & 94.7 & RCP/ASTM + Gluc \\
\hline RCP C2 & Pseudomonas sp. K94.08 & 100 & RCP/ASTM + Gluc \\
\hline RCPCd 1 & Acidovorax sp. BSB421 & 100 & $\mathrm{RCP}+\mathrm{Cd} / \mathrm{ASTM}$ \\
\hline RCPCd 7 & Agrobacterium tumefaciens CFBP2712 & 100 & $\mathrm{RCP}+\mathrm{Cd} / \mathrm{ASTM}$ \\
\hline RCPCd A2 & Uncultured bacterium AKIW473 & 86.8 & RCP + Cd/ASTM + Gluc + Cd \\
\hline RCPCd E1 & Pseudomonas sp. NZ039 & 100 & RCP + Cd/ASTM + Gluc \\
\hline
\end{tabular}




\subsection{Measurement of cadmium concentrations in plants}

Metal measurements in Lemna plants usually involve large amounts of plant material, due to the high water content of the plants. Because our samples were relatively small, we used less plant material, and attempted to measure single plants in order to quantify the variation in metal accumulation between individual plants. While single plants produced too little dry material for analysis in previous studies, we were able to successfully measure samples of 2-3 plants in most cases, except the few plant/bacterial combinations where bacteria caused extreme deterioration of plant biomass over the treatment period so that there was almost no material left.

Plant material was digested using a CEM Mars Xpress closed vessel microwave digestion system (CEM Corporation, Matthews, NC). For each sample, $0.02-0.1 \mathrm{~g}$ of plant material (wet weight) were digested by adding concentrated $\mathrm{HNO}_{3}$ and $30 \%$ hydrogen peroxide, following the protocol of Wu et al. (Wu et al., 1997). Sample volume was diluted to $50 \mathrm{ml}$ with double distilled water before the measurements. The cadmium concentration in the samples was measured by using inductively coupled plasma-optical emission spectroscopy (ICP-OES) on a Perkin-Elmer Optima 4300 DV analyzer (Perkin Elmer, Shelton, CT). The level of detection for Cd was $0.62 \mu \mathrm{g} / \mathrm{g}$.

\subsection{Nucleotide sequence accession numbers}

Nucleotide sequences were submitted to GenBank with the accession numbers DQ922740 to DQ922765 for isolate 16S rRNA sequences.

\section{Results}

\subsection{Analysis of bacterial isolates from plants}

Isolates were identified by $16 \mathrm{~S}$ rRNA gene analysis. Isolates from EPA plants were most closely related to members of the genera Flavobacterium (Sporocytophaga), Microbacterium, Flectobacillus, Limnobacter, and Methylobacterium. Organisms related to Caulobacter and Microbacterium were only found in EPA treatments without added cadmium. RCP isolates included members of the genera Variovorax, Agrobacterium, Methylophilus, Pseudomonas, Zoogloea, Duganella (Oxalobacteraceae), and Acidovorax (Table 3, Supplemental Fig. S4).

Isolation techniques successfully utilized media based on either plant extract or on glucose as a carbon source. Almost all bacteria initially isolated on plant extract medium were able to also grow on medium with glucose as the sole carbon source.

\subsection{Characterization of metal tolerance}

Plants from the four different treatments (EPA, EPA + Cd, RCP, or RCP $+\mathrm{Cd}$ ) were placed on solid media plates with or without cadmium. EPA plants that had not been exposed to cadmium did not yield bacterial growth on plates with cadmium. However, for RCP plants which have a history of exposure to Cd in their natural setting, bacteria grew on plates with cadmium whether plants had been exposed to added cadmium in laboratory microcosms or not. In liquid culture experiments measuring bacterial growth at different cadmium concentrations over time, several growth patterns emerged for different isolates. Some isolates only grew in medium without cadmium (isolates RCP C1, RCP 9, RCPCd A2, RCPCd 1, RCPCd 7, EPA 6, EPACd 7, and EPACd 12); others showed growth at first only in medium without cadmium, and after a lag phase of $24-40 \mathrm{~h}$, grew also in concentrations of cadmium between 0.1 and $0.6 \mathrm{mM}$ (isolates RCP C2 (Fig. 1), RCP5, RCP 6, RCPCd E1, EPA 5, and EPACd 10) (Supp. Figs. S1a-g). No isolates were able to grow in concentrations above $0.6 \mathrm{mM} \mathrm{Cd}$.

\subsection{Phytoextraction of cadmium with added bacteria}

We chose to focus on the effects of isolates on EPA axenic plants due to these plants' greater sensitivity to metals compared to RCP plants (Table 2). EPA plants grown with fourteen different bacterial isolates (Table 3) were measured at the end of 14 days to determine the effect of select bacteria on plant growth and cadmium phytoextraction. Criteria chosen were frond counts, root length, final $\mathrm{pH}$ of medium, and cadmium concentrations in plants. A small amount of glucose was added to the medium to enrich bacterial growth. In previous tests by other research groups, sucrose was used, especially to test for contamination of axenic plants (Crowley et al., 1992; Srivastava and Appenroth, 1995); however, in our initial experiments, no visible growth was observed in sucrose. Isolates showed growth on plates amended with glucose, and so were expected to grow in plant medium with glucose. Several isolates (5 out of the 14 unique isolates) showed poor microbial growth (as evidenced by no turbidity) or led to poor plant growth in the liquid test medium with added cadmium and glucose, including RCP 9, RCPCd 1, RCPCd E1, RCPCd A2, and EPACd 7. Plants inoculated with these bacteria were not measured for cadmium accumulation, due to either no observable microbial growth or extremely little plant biomass production, and in some cases extreme deterioration of biomass so that almost no plant material was left

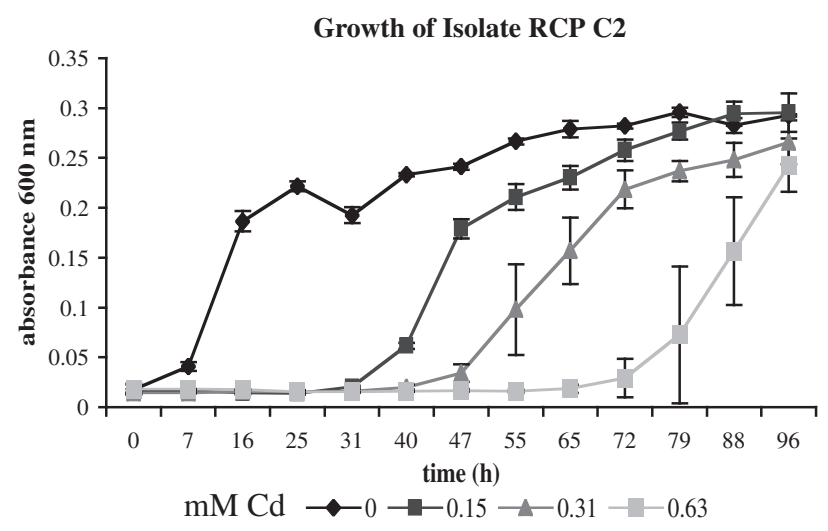

Fig. 1 - Growth curve of representative isolate RCP C2 exposed to $\mathrm{Cd}^{2+}$ concentrations ranging from 0 to $10 \mathrm{mM}$. Absorption at $600 \mathrm{~nm}$ is used as a proxy for cell density. Isolates with similar patterns to RCP C2 include RCP 5, RCP 6, RCPCd E1, EPA 5, and EPACd 10. Growth curves for all isolates that grew in cadmium are detailed in the supplemental data (S1a-g). 
in the tubes. Root length, final pH of the medium, and growth rate of these plants were measured. These plants had very short roots, which were not significantly longer than the sterilized plant control, the $\mathrm{pH}$ values of the growth medium after two weeks were not significantly lower than the sterile plant control, and growth rates were significantly lower than the sterilized plant control.

Cadmium accumulation was measured in plants inoculated with nine different isolates individually and as a mixture. Accumulation was high in the axenic control without bacteria, and the lowest accumulation was observed in tubes where a combination of all isolates had been added (Fig. 2a). Significant differences were seen when comparing the control without bacteria to different combinations of isolates RCP all, EPA all, RCP and EPA all, RCP C2 (Pseudomonas sp.) only, and EPA 6 (Microbacterium sp.) only, all of which accumulated less cadmium than the axenic control (Supp. Table S1).

Root length was directly correlated with bacterial growth. Roots were longer in all isolate treatments where bacterial growth was observed (Fig. 2b). In controls without bacteria, roots were very short $(0.5 \mathrm{~cm})$, whereas individual isolates EPACd 10 (Flavobacterium sp.), EPACd 12 (Limnobacter sp.), EPA 6 (Microbacterium sp.), and RCP 6 (Oxalobacteraceae), and the mixtures of isolates had much longer roots (Fig. 2b). When comparing $p$ values derived from Student's t-tests, most isolates had significantly increased root length compared to the control without added bacteria (Supp. Table S1).

As with root length, the final $\mathrm{pH}$ value of the medium for every isolate tested was significantly lower than the treatment with no added bacteria, except in the cases where there was no bacterial growth observed (Fig. 2c, Supp. Table S1). When comparing plant growth rates based on frond count, most treatments with bacterial growth were not significantly different from the control without added bacteria (Fig. 2d, Supp. Table S1, Supp. Table S2).

Bacteria influenced plant growth negatively in some cases, especially for isolates RCP C1 (Zoogloea sp.) and RCPCd E1 (Pseudomonas sp.), where there was very limited frond replication in the 14 day test period, and fronds turned white by the end of the experiment.

When comparing frond counts, final medium $\mathrm{pH}$, final root length, and cadmium accumulation, there was a strong negative correlation between cadmium accumulation and root length $(r=-0.70)$. There was no correlation between cadmium accumulation and growth rate $(r=-0.04)$, and only a weak positive correlation between cadmium accumulation and $\mathrm{pH}(r=0.45)$. There was also a weak positive correlation between root length and growth rate $(r=0.51)$, a weak negative correlation between root length and $\mathrm{pH}(r=-0.56)$ and a weak negative correlation between growth rate and $\mathrm{pH}(r=-0.42)$.

\subsection{Plant growth promotion by siderophore production}

Siderophore production was determined by the CAS plate method. Clearing or changing of the medium from blue to orange was seen in isolates EPA 5, RCP 9, RCPCd A2, RCP C1, RCP C2, and RCPCd E1 (see Supp. Fig. S2). RCP 9, RCPCd A2, and RCPCd E1 were among the isolates tested with plants that showed poor plant growth or no bacterial growth as indicated by turbidity and were not measured for Cd accumulation. Isolate RCP C1 also led to poor plant growth. While plants inoculated with isolate RCP C2 showed significant Cd accumulation, neither RCP C2 nor EPA 5 led to more root elongation
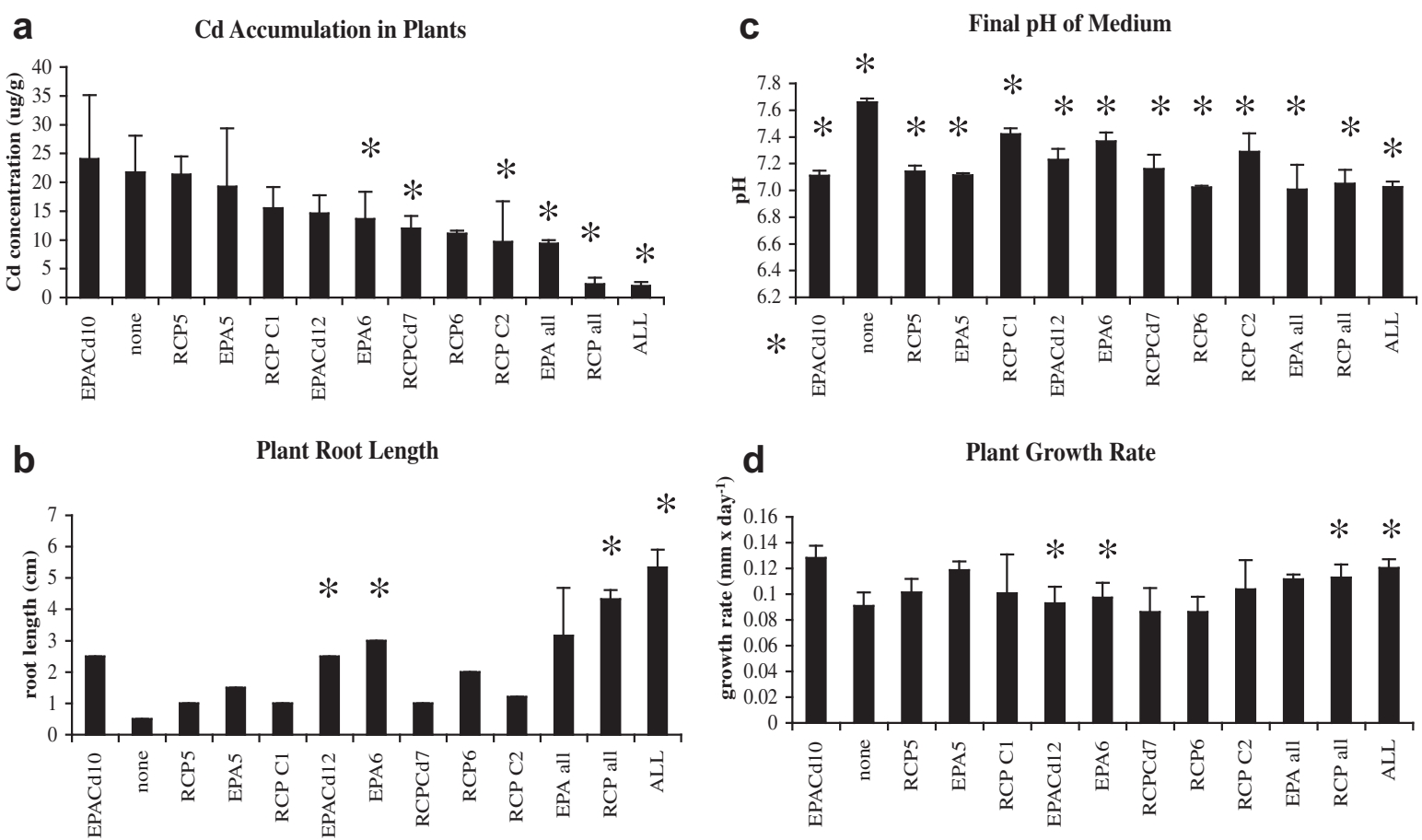

Fig. 2 - Comparisons of a. Cd accumulation, b. root length, c. final pH value of the plant incubation water, and d. plant growth rate, for axenic plants after inoculation with select, none, or all bacterial isolates. 
than non-siderophore producing isolates such as EPACd 10, EPACd 12, EPA 6, or RCP 6.

\section{Discussion}

Our findings indicate that plant growth promoting bacteria play a role in metal accumulation by L. minor. We demonstrate that selective addition of formerly plant root associated bacteria not only have a phytoprotective effect and improve the heavy metal tolerance of the plant, but also that the presence of these isolates lead to longer root zones thus improving heavy metal phytoremediation over an extended root zone.

In previous studies (Stout and Nüsslein, 2005) 16S rRNA gene clone library analyses identified the $\beta$-proteobacteria as the dominant group amongst bacterial rhizoplane communities on these plants, regardless of cadmium exposure. In this study bacteria isolated from EPA or RCP Lemna roots either exposed or not exposed to cadmium again belonged mostly to the proteobacteria, specifically the $\beta$-proteobacteria, although the most dominant species found in clone libraries were not isolated here. It is often the case that the most readily cultured organisms do not appear the most frequently or even at all in clone libraries (Eilers et al., 2000; Zhang et al., 2007). While we expect that many organisms that are not culturable will only appear as sequences in clone libraries due to the bias we know exists in microbial culturing techniques, the opposite, where bacteria that have been cultured from a particular site are not detected in a clone library, may also occur due to biases in DNA extraction and PCR methods that may select against extraction of DNA from certain difficult-to-lyse cells (Simbahan et al., 2005).

Depending on growth conditions and media used, E. coli can tolerate cadmium at levels as high as $0.5 \mathrm{mM}$, whereas the metal-resistant Ralstonia metallidurans CH34 can tolerate levels of cadmium ten times as high, up to $5 \mathrm{mM}$ (Nies, 2000). However, environmental isolates from a plant rhizosphere were found to be susceptible to concentrations as low as $0.1 \mathrm{mM}$ (Abou-Shanab et al., 2007). Our screening of isolates for tolerance to elevated levels of cadmium (above $0.1 \mathrm{mM}$ ) revealed that after an initial lag phase, certain isolates either from RCP plants or EPA plants that had been exposed to cadmium were able to grow in elevated concentrations. We expected that due to a history of contaminant exposure, RCP isolates would be more tolerant to $\mathrm{Cd}$ than those isolates from EPA plants, and to some degree this was the case. The phenomenon of increased metal tolerance with preexposure has been described by others (Lehmann et al., 1999; Díaz-Raviña and Bååth, 2001). Possible explanations for this initial lag phase followed by growth in cadmium could be due to time or concentrations necessary for induction of metal resistance efflux systems, or the time necessary for EPS production, or expression of additional adaptations.

Cadmium tolerance may also vary based on whether the bacterium is found in a planktonic state or attached to plant roots. Bacteria attached to plant surfaces may be more metal tolerant due to protection offered by the plant (Andrews and Harris, 2000) or by their location within a biofilm. When these bacteria are isolated from the plant, they may not be able to withstand exposure to metal concentrations in the medium.

Preadaptation to heavy metals does seem to play an important role in determining whether a bacterium will be able to tolerate higher concentrations of cadmium. In an earlier study, we plated bacteria rinsed from plant roots, either from EPA plants grown without cadmium for two weeks, or grown with cadmium for two weeks, on cadmiumcontaining medium. Bacterial growth on cadmium plates was much greater from EPA plants grown with Cd than for EPA plants grown with no Cd (Supp. Fig. 3).

Microbial isolates from EPA plants were most closely related to members of the genera Flavobacterium, a common aquatic bacterium also found in the rhizospheres of plants such as young barley (Johansen et al., 2009); Microbacterium, of which the species Microbacterium azadirachtae is known as a plant-growth promoting bacterium isolated from seedlings (Madhaiyan et al., 2010); Flectobacillus, isolated from eutrophic lake water (Hahn et al., 1999); Limnobacter, a thiosulfate oxidizer from a freshwater lake (Spring et al., 2001); and Methylobacterium a plant growth promoting bacterium (Madhaiyan et al., 2006). RCP isolates included members of the genera Variovorax, a rhizosphere bacterium (Belimov et al., 2005); Methylophilus, a rhizosphere bacterium, a strain of which was isolated from rice (Madhaiyan et al., 2009); Pseudomonas, Agrobacterium, Zoogloea, found in sewage treatment water (Solisio et al., 1998); Duganella Zoogloea, (Hiraishi et al., 1997), and Acidovorax, some species of which are plant pathogens (Hu and Young, 1998).

Several of the isolates from this study have been associated with plants and metal contaminants. A strain of Methylobacterium oryzae was found to reduce toxicity of $\mathrm{Ni}$ and $\mathrm{Cd}$ to tomato plants, promoting plant growth and reducing metal accumulation in plants while binding metal to bacterial cells (Madhaiyan et al., 2007). Variovorax and Flavobacterium were found to promote root growth and showed tolerance to cadmium (Belimov et al., 2005; Piotrowska-Seget et al., 2005). In our studies, Variovorax (RCP 9) did not show elevated tolerance to cadmium, which could be due to metal concentrations tested, strain differences including the ability to form EPS, medium composition, loss of resistance plasmids, or a number of additional factors.

Treatments with the combination of isolates as inocula (all RCP isolates, all EPA isolates, or a mixture of all isolates), induced the greatest root elongation and least cadmium phytoextraction, while the axenic plant control, along with two of our isolates, showed the greatest cadmium accumulation by the plant while the roots stayed shorter. We had initially thought that the increased surface area of a longer root would enable more bacterial biomass, and that more bacterial biomass could adsorb more Cd thus protecting the plant. Biomass measurements revealed that this was not the case, and that the differences in metal update by the plants are rather an effect of individual isolates. Synergistic interactions between bacteria in plant growth promotion have been described in numerous other studies (Anandham et al., 2007; Domenech et al., 2006; Kannan and Sureendar, 2009), and it is quite possible that in our study, synergistic interactions amongst bacteria increase root elongation and also act to keep cadmium out of plants. 
Some researchers (Belimov et al., 2001) found that inoculating axenic plants with root growth promoting bacteria increased root length but did not significantly increase the uptake of metals, although they also did not see significant inhibition of metal accumulation. They attributed the lessening of toxicity symptoms in plants to associated bacteria, most likely due to bacterial inhibition of ethylene, a plant hormone often produced under stress conditions that inhibit root growth. Siderophore production was found in isolates associated with fairly high plant cadmium accumulation but not necessarily with increased root length. Other isolates associated with high cadmium accumulation in plants and increased root length did not produce siderophores, and so siderophore production may not play a primary role in root elongation. Certain siderophores, however, while associated with iron chelation, may chelate zinc or cadmium (Mishra et al., 2009) and so a role for siderophores in cadmium phytoextraction could be investigated further.

\section{Conclusions}

Over the period of time investigated, we demonstrated that bacteria had an effect on cadmium accumulation in the EPA strain of L. minor. Plants with longer roots, and more root surface area for rhizoplane bacteria to adsorb Cd to their surfaces, showed less Cd accumulation than those plants with shorter roots and no bacteria. Our findings indicate that plantgrowth promoting bacteria play a role in metal accumulation by L. minor, but it may be more of a phytoprotective role than initially thought. This research brings us one step closer to the application of selective root associated bacteria as a strategy to improve the metal tolerance of plants used in the phytoremediation of metal contaminants.

\section{Acknowledgements}

The authors wish to thank Guy R. Lanza for assistance with this project. This work was supported by Alice and Larry Shepard (L. S.), and by a University of Massachusetts Healey Endowment grant to K. N.

\section{Appendix. Supplementary material}

Supplementary data associated with this article can be found in the online version, at doi:10.1016/j.watres.2010.07.073.

\section{R E F E R E N C E S}

Abhilash, P.C., Pandey, V.C., Srivastava, P., Rakesh, P.S., Chandran, S., Singh, N., Thomas, A.P., 2009. Phytofiltration of cadmium from water by Limnocharis flava (L.) Buchenau grown in free-floating culture system. J. Hazard. Mater. 170, 791-797.

Abou-Shanab, R.A., van Berkum, P., Angle, J.S., 2007. Heavy metal resistance and genotypic analysis of metal resistance genes in gram-positive and gram-negative bacteria present in Ni-rich serpentine soil and in the rhizosphere of Alyssum murale. Chemosphere 68, 360-367.

Agunbiade, F.O., Olu-Owolabi, B.I., Adebowale, K.O., 2009. Phytoremediation potential of Eichornia crassipes in metalcontaminated coastal water. Bioresour. Technol. 100, 4521-4526.

Anandham, R., Sridar, R., Nalayini, P., Poonguzhali, S., Madhaiyan, M., Sa, T., 2007. Potential for plant growth promotion in groundnut (Arachis hypogaea L.) cV. ALR-2 by co-inoculation of sulfur-oxidizing bacteria and Rhizobium. Microbiol. Res. 162 (2), 139-153.

Andrews, J.H., Harris, R.F., 2000. The ecology and biogeography of microorganisms on plant surfaces. Annu. Rev. Phytopathol. 38, 145-180.

APHA, AWWA, WEF, 1992. Standard Methods for the Examination of Water and Wastewater. American Public Health Association/American Water Works Association/ Water Environment Federation, Washington, D.C.

Baker, A.J.M., Brooks, R.R., 1989. Terrestrial higher plants which hyperaccumulate metallic elements-a review of their distribution, ecology, and phytochemistry. Biorecovery 1, 81-126.

Belimov, A.A., Safronova, V.I., Sergeyeva, T.A., Egorova, T.N., Matveyeva, V.A., Tsyganov, V.E., Borisov, A.Y., Tikhonovich, I.A., Kluge, C., Preisfeld, A., Dietz, K.J., Stepanok, V.V., 2001. Characterization of plant growth promoting rhizobacteria isolated from polluted soils and containing 1-aminocyclopropane1-carboxylate deaminase. Can. J. Microbiol. 47, 642-652.

Belimov, A.A., Hontzeas, N., Safronova, V.I., Demchinskaya, S.V., Piluzza, G., Bullitta, S., Glick, B.R., 2005. Cadmium-tolerant plant growth-promoting bacteria associated with the roots of Indian mustard (Brassica juncea L. Czern.). Soil Biol. Biochem. 37, 241-250.

Cole, J.R., Chai, B., Marsh, T.L., Farris, R.J., Wang, Q., Kulam, S.A., Chandra, S., McGarrell, D.M., Schmidt, T.M., Garrity, G.M., Tiedje, J.M., 2003. The Ribosomal Database Project (RDP-II): previewing a new autoaligner that allows regular updates and the new prokaryotic taxonomy. Nucleic Acids. Res. 31, 442-443.

Crowley, D.E., Romheld, V., Marschner, H., Szaniszlo, P.J., 1992. Root-microbial effects on plant iron uptake from siderophores and phytosiderophores. Plant Soil 142, 1-7.

Das, P., Samantaray, S., Rout, G.R., 1997. Studies on cadmium toxicity in plants: a review. Environ. Pollut. 98, 29-36.

De Souza, M.P., Huang, C.P.A., Chee, N., Terry, N., 1999. Rhizosphere bacteria enhance the accumulation of selenium and mercury in wetland plants. Planta 209, 259-263.

Debusk, T.A., Laughlin Jr., R.B., Schwartz, L.N., 1996. Retention and compartmentalization of lead and cadmium in wetland microcosms. Water Res. 30, 2707-2716.

Department Of Health And Human Services, 2008. Public Health Service Agency for Toxic Substances and Disease Registry, Public Health Statement Cadmium, CAS 7440-43-9.

Díaz-Raviña, M., Bååth, E., 2001. Response of soil bacterial communities pre-exposed to different metals and reinoculated in an unpolluted soil. Soil Biol. Biochem. 33, 241-248.

Domenech, J., Reddy, M.S., Kloepper, J.W., Ramos, B., GutierrezMañero, J., 2006. Combined application of the biological produce LS213 with Bacillus, Pseudomonas, or Chryseobacterium for growth promotion and biological control of soil-borne diseases in pepper and tomato. BioControl 51, 245-258.

Eilers, H., Pernthaler, J., Glockner, F.O., Amann, R., 2000. Culturability and in situ abundance of pelagic bacteria from the North Sea. Appl. Environ. Microbiol. 66, 3044-3051.

Flathman, P.E., Lanza, G.R., 1998. Phytoremediation: current views on an emerging green technology. J. Soil Contam. 7, 415-432. 
Gadd, G.M., 1992. Metals and microorganisms: a problem of definition. FEMS Microbiol. Lett. 79, 197-203.

Ghassemzadeh, F., Yousefzadeh, H., Arbab-Zavar, M.H., 2008. Removing arsenic and antimony by Phragmites australis: rhizofiltration technology. J. Appl. Sci. 8, 1668-1675.

GLEC, 2000. Update of Ambient Water Quality Criteria for Cadmium. Great Lakes Environmental Center/U.S. Environmental Protection Agency/Office of Water, Traverse City, MI.

Hahn, M.W., Moore, E.R., Hofle, M.G., 1999. Bacterial filament formation, a defense mechanism against flagellate grazing, is growth rate controlled in bacteria of different phyla. Appl. Environ. Microbiol. 65 (1), 25-35.

Hall, T.A., 1999. BioEdit: a user-friendly biological sequence alignment editor and analysis program for Windows. Nucleic Acids Symp. Ser. 41, 95-98.

Hasar, H., Obek, E., 2001. Removal of toxic metals from aqueous solution by duckweed (Lemna minor L): role of harvesting and adsorption isotherms. Arab. J. Sci. Eng. 26, 47-54.

Hiraishi, A., Shin, Y.K., Sugiyama, J., 1997. Proposal to reclassify Zoogloea ramigera IAM 12670 (P.R. Dugan 115) as Duganella zoogloeoides gen. nov., sp. nov. Int. J. Syst. Bacteriol. 47 (4), 1249-1252.

Hou, W., Chen, X., Song, G., Wang, Q., Chi Chang, C., 2007. Effects of copper and cadmium on heavy metal polluted waterbody restoration by duckweed (Lemna minor). Plant Physiol. Biochem. 45, 62-69.

Hu, F.P., Young, J.M., 1998. Biocidal activity in plant pathogenic Acidovorax, Burkholderia, Herbaspirillum, Ralstonia and Xanthomonas spp. J. Appl. Microbiol. 84 (2), 263-271.

Huber, T., Faulkner, G., Hugenholtz, P., 2004. Bellerophon: a program to detect chimeric sequences in multiple sequence alignments. Bioinformatics 20, 2317-2319.

Huebert, D.B., Shay, J.M., 1991. The effect of cadmium and its interaction with external calcium in the submerged aquatic macrophyte Lemna trisulca L. Aquat. Toxicol. 20, 57-72.

Ingole, N.W., Bhole, A.G., 2003. Removal of heavy metals from aqueous solution by water hyacinth (Eichhornia crassipes). J. Water Supply Res. T 52, 119-128.

Johansen, J.E., Nielsen, P., Binnerup, S.J., 2009. Identification and potential enzyme capacity of flavobacteria isolated from the rhizosphere of barley (Hordeum vulgare L.). Can. J. Microbiol. 55 (3), 234-241.

Joshi, P.M., Juwarkar, A.A., 2009. In vivo studies to elucidate the role of extracellular polymeric substances from Azotobacter in immobilization of heavy metals. Environ. Sci. Technol. 43, $5884-5889$.

Kannan, V., Sureendar, R., 2009. Synergistic effect of beneficial rhizosphere microflora in biocontrol and plant growth promotion. J. Basic Microbiol. 49 (2), 158-164.

Khellaf, N., Zerdaoui, M., 2009. Phytoaccumulation of zinc by the aquatic plant, Lemna gibba L. Bioresour. Technol. 100, 6137-6140.

Klaassen, C.D., Liu, J., Choudhuri, S., 1999. Metallothionein: an intracellular protein to protect against cadmium toxicity. Annu. Rev. Pharmacol. Toxicol. 39 (1), 267-294.

Kumar, S., Tamura, K., Nei, M., 2004. MEGA3: integrated software for molecular evolutionary genetics analysis and sequence alignment. Brief. Bioinformatics. 5, 150-163.

Landolt, E., Kandeler, R., 1987. The Family of Lemnaceae-A Monographic Study. In: Phytochemistry, Physiology, Application, Bibliography, vol. 2. Veröffentlichungen des Geobotanischen Institutes der ETH, Stiftung Rübel, Zürich.

Lane, T.W., Saito, M.A., George, G.N., Pickering, I.J., Prince, R.C., Morel, F.M., 2005. Biochemistry: a cadmium enzyme from a marine diatom. Nature $435,42$.

Lehmann, V.V., Tubbing, G.M., Admiraal, W., 1999. Induced metal tolerance in microbenthic communities from three lowland rivers with different metal loads. Arch. Environ. Contam. Toxicol. 36, 384-391. van der Lelie, D., Corbisier, P., Diels, L., Gills, A., Lodewyckx, C., Mergeay, M., Taghavi, S., Spelmans, N., Vangronsveld, J., 2000. In: Terry, N., Banuelos, G.S. (Eds.), Phytoremediation of Contaminated Soil and Water. Lewis Publishers, Boca Raton, FL, pp. 265-281.

Leveau, J.H., Lindow, S.E., 2005. Utilization of the plant hormone indole-3-acetic acid for growth by Pseudomonas putida strain 1290. Appl. Environ. Microbiol. 71, 2365-2371.

Lodewyckx, C., Mergeay, M., Vangronsveld, J., Clijsters, H., van der Lelie, D., 2002. Isolation, characterization, and identification of bacteria associated with the zinc hyperaccumulator Thlaspi caerulescens subsp. calaminaria. Int. J. Phytoremediat. 4, 101-115.

Madhaiyan, M., Suresh Reddy, B.V., Anandham, R., Senthilkumar, M., Poonguzhali, S., Sundaram, S.P., Sa, T., 2006. Plant growth-promoting Methylobacterium induces defense responses in groundnut (Arachis hypogaea L.) compared with rot pathogens. Curr. Microbiol. 53 (4), 270-276.

Madhaiyan, M., Poonguzhali, S., Sa, T., 2007. Metal tolerating methylotrophic bacteria reduces nickel and cadmium toxicity and promotes plant growth of tomato (Lycopersicon esculentum L.). Chemosphere 69 (2), 220-228.

Madhaiyan, M., Poonguzhali, S., Kwon, S.W., Sa, T.M., 2009. Methylophilus rhizosphaerae sp. nov., a restricted facultative methylotroph isolated from rice rhizosphere soil. Int. J. Syst. Evol. Microbiol. 59 (Pt 11), 2904-2908.

Madhaiyan, M., Poonguzhali, S., Lee, J.S., Lee, K.C., Saravanan, V.S., Santhanakrishnan, P., 2010. Microbacterium azadirachtae sp. nov., a plant-growth-promoting actinobacterium isolated from the rhizoplane of neem seedlings. Int. J. Syst. Evol. Microbiol. 60 (Pt 7), 1687-1692.

Del-Campo Marin, C.M., Oron, G., 2007. Boron removal by the duckweed Lemna gibba: a potential method for the remediation of boron-polluted waters. Water Res. 41, $4579-4584$.

Megateli, S., Semsari, S., Couderchet, M., 2009. Toxicity and removal of heavy metals (cadmium, copper, and zinc) by Lemna gibba. Ecotoxicol. Environ. Saf. 72, 1774-1780.

Mishra, B., Haack, E.A., Maurice, P.A., Bunker, B.A., 2009. Effects of the microbial siderophore DFO-B on $\mathrm{Pb}$ and $\mathrm{Cd}$ speciation in aqueous solution. Environ. Sci. Technol. 43, 94-100.

Mishra, V.K., Tripathi, B.D., 2009. Accumulation of chromium and zinc from aqueous solutions using water hyacinth (Eichhornia crassipes). J. Hazard. Mater. 164, 1059-1063.

Mkandawire, M., Lyubun, Y.V., Kosterin, P.V., Dudel, E.G., 2004a. Toxicity of arsenic species to Lemna gibba L. and the influence of phosphate on arsenic bioavailability. Environ. Toxicol. 19, 26-34.

Mkandawire, M., Tauert, B., Dudel, E.G., 2004b. Capacity of Lemna gibba L. (Duckweed) for uranium and arsenic phytoremediation in mine tailing waters. Int. J. Phytoremediat 6, 347-362.

Nies, D.H., 2000. Heavy metal-resistant bacteria as extremophiles: molecular physiology and biotechnological use of Ralstonia sp. CH34. Extremophiles 4, 77-82.

Nies, D.H., 2003. Efflux-mediated heavy metal resistance in prokaryotes. FEMS Microbiol. Rev. 781, 1-27.

Oporto, C., Arce, O., Van den Broeck, E., Van der Bruggen, B., Vandecasteele, C., 2006. Experimental study and modelling of $\mathrm{Cr}$ (VI) removal from wastewater using Lemna minor. Water Res. 40, 1458-1464.

Pagnanelli, F., Esposito, A., Toro, L., Vegliò, F., 2003. Metal speciation and $\mathrm{pH}$ effect on $\mathrm{Pb}, \mathrm{Cu}, \mathrm{Zn}$ and $\mathrm{Cd}$ biosorption onto Sphaerotilus natans: Langmuir-type empirical model. Water Res. 37, 627-633.

Piotrowska-Seget, Z., Cycon, M., Kozdrój, J., 2005. Metal-tolerant bacteria occurring in heavily polluted soil and mine spoil. Appl. Soil Ecol 28, 237-246. 
Rahman, M.A., Hasegawa, H., Ueda, K., Maki, T., Okumura, C., Rahman, M.M., 2007. Arsenic accumulation in duckweed (Spirodela polyrhiza L.): a good option for phytoremediation. Chemosphere 69, 493-499.

Roane, T.M., Pepper, I.L., 1999. Microbial Responses to environmentally toxic cadmium. Microb. Ecol. 38, 358-364.

Salt, D.E., Blaylock, M., Kumar, N.P., Dushenkov, V., Ensley, B.D., Chet, I., Raskin, I., 1995. Phytoremediation: a novel strategy for the removal of toxic metals from the environment using plants-review. BioTechnology 13, 468-474.

Salt, D.E., Benhamou, N., Leszczyniecka, M., Raskin, I., 1999. A possible role for Rhizobacteria in water treatment by plant roots. Int. J. Phytoremediat. 1, 67-79.

Schwyn, B., Neilands, J.B., 1987. Universal chemical assay for the detection and determination of siderophores. Anal. Biochem. 160, 47-56.

Simbahan, J., Kurth, E., Schelert, J., Dillman, A., Moriyama, E., Jovanovich, S., Blum, P., 2005. Community analysis of a mercury hot spring supports occurrence of domain-specific forms of mercuric reductase. Appl. Environ. Microbiol. 71, 8836-8845.

Snook, H., 1996. Rice City Pond 319 Project, United States Environmental Protection Agency, Lexington, MA.

Solisio, C., Lodi, A., Converti, A., Del Borghi, M., 1998. Cadmium, zinc, and chromium(III) removal from aqueous solutions by Zoogloea ramigera. Chem. Biochem. Eng. Q. 12, 45-49.

Spring, S., Kampfer, P., Schleifer, K.H., 2001. Limnobacter thiooxidans gen. nov., sp. nov., a novel thiosulfate-oxidizing bacterium isolated from freshwater lake sediment. Int. J. Syst. Evol. Microbiol. 51 (Pt 4), 1463-1470.

Srivastava, A., Appenroth, K.-J., 1995. Interacion of EDTA and iron on the accumulation of $\mathrm{Cd}^{2+}$ in duckweeds (Lemnaceae). J. Plant. Physiol. 146, 173-176.

Stout, L.M., Nüsslein, K., 2005. Shifts in rhizoplane communities of aquatic plants after cadmium exposure. Appl. Environ. Microbiol. 71, 2484-2492.

Trevors, J.T., Stratton, G.W., Gadd, G.M., 1986. Cadmium transport, resistance, and toxicity in bacteria, algae, and fungi. Can. J. Microbiol. 32 (6), 447-464.

USEPA, 1996. Ecological Effects Test Guidelines: OPPTS 850.4400. Aquatic plant toxicity test using Lemna spp., tiers I and II, pp. 1-10, United States Environmental Protection Agency.
USEPA, 2004. List of contaminants and their maximum contaminant levels (MCLs), United States Environmental Protection Agency.

USGS, 2004. Water quality samples for Massachusetts, United States Geological Society.

Uysal, Y., Taner, F., 2009. Effect of pH, temperature, and lead concentration on the bioremoval of lead from water using Lemna minor. Int. J. Phytoremediat. 11, 591-608.

Wang, W., 1990. Literature review on duckweed toxicity testing. Environ. Res. 52, 7-22.

Wang, Q., Cui, Y., Dong, Y., 2002. Phytoremediation of polluted waters: potentials and prospects of wetland plants. Acta Biotechnol. 22, 199-208.

Weisburg, W.G., Barns, S.M., Pelletier, D.A., Lane, D.J., 1991. $16 \mathrm{~S}$ ribosomal DNA amplification for phylogenetic study. J. Bacteriol. 173, 697-703.

Whiting, S.N., Reeves, R.D., Richards, D., Johnson, M.S., Cooke, J.A., Malaisse, F., Paton, A., Smith, J.A.C., Angle, J.S., Chaney, R.L., Ginocchio, R., Jaffre, T., Johns, R., McIntyre, T., Purvis, O.W., Salt, D.E., Schat, H., Zhao, F.J., Baker, A.J.M., 2004. Research priorities for conservation of metallophyte biodiversity and their potential for restoration and site remediation. Restor. Ecol. 12, 106-116.

Wright, R., Viator, O.J., Michaelis, B., 2004. Dry Weather Water Quality Sampling and Modeling-Blackstone River Feasibility Study: Phase 1: Water Quality Evaluation and Modeling of the MA Blackstone River. United States Army Corps of Engineers.

Wu, S., Feng, X., Wittmeier, A., 1997. Microwave digestion of plant and grain reference materials in nitric acid or a mixture of nitric acid and hydrogen peroxide for the determination of multi-elements by inductively coupled plasma mass spectrometry. J. Anal. Atom. Spectrom. 12, 797-806.

Zayed, A., Gowthaman, S., Terry, N., 1998. Phytoaccumulation of trace elements by wetland plants: I. Duckweed. J. Environ. Qual. 27, 715-721.

Zhang, H.B., Yang, M.X., Shi, W., Zheng, Y., Sha, T., Zhao, Z.W., 2007. Bacterial diversity in mine tailings compared by cultivation and cultivation-independent methods and their resistance to lead and cadmium. Microb. Ecol. 54, 705-712.

Zhu, Y.L., Zayed, A.M., Qian, J.-H., deSouza, M., Terry, N., 1999. Phytoaccumulation of trace elements by wetland plants: II. Water Hyacinth. J. Environ. Qual. 28, 339-344. 